\title{
TINJAUAN TERHADAP MODEL BISNIS PENYELENGGARAAN PENYIARAN TV DIGITAL
}

\author{
Daniel P. Hutabarat \\ Jurusan Sistem Komputer, Fakultas Ilmu Komputer, Universitas Bina Nusantara, \\ Jln. K.H. Syahdan No. 9, Kemanggisan, Palmerah, Jakarta Barat 11480 \\ dhutabarat@binus.edu
}

\begin{abstract}
TV broadcast systems are migrating from analogue to digital broadcasting system. Some countries in the world have completed this migration since a few years ago. America decided to stop broadcasting analog television in 2009. In Asia, Singapore launched this technology in 2004 and Malaysia implemented in 2006 (Depkominfo, 2009). With so many countries are migrating to digital broadcasting system, there are many business models that can be referred for organizing digital television broadcasts. In this writing, several business models that are used in the world will be reviewed and analyzed and the results can be a reference to determine the appropriate business model according to the organizers.
\end{abstract}

Keywords: business model, migration, digital broadcasting, television

\begin{abstract}
ABSTRAK
Sistem penyiaran televisi saat ini mulai bermigrasi dari sistem siaran analog ke digital. Beberapa negara di dunia, sudah melakukan migrasi ini sejak beberapa tahun yang lalu. Amerika, sudah memutuskan untuk menghentikan penyiaran televisi analognya secara total di tahun 2009. Di Asia, Singapura meluncurkan teknologi ini di tahun 2004 dan Malaysia sudah mengoperasikannya di tahun 2006 (Depkominfo, 2009). Dengan banyaknya negara yang bermigrasi ke sistem siaran digital banyak pulalah model bisnis yang dapat menjadi acuan dalam menyelenggarakan siaran televisi digital. Pada tulisan ini, akan ditinjau beberapa model bisnis yang digunakan di dunia dan kemudian akan dilakukan analisis untuk kemudian hasilnya dapat menjadi acuan untuk menentukan model bisnis mana yang sesuai dengan pihak penyelenggara.
\end{abstract}

Kata kunci: model bisnis, migrasi, penyiaran digital, televisi 


\section{PENDAHULUAN}

Perubahan dari sistem penyiaran analog ke sistem penyiaran digital merupakan hal yang tidak bisa dihindari. Banyak negara sudah bersepakat untuk menghentikan semua penyiaran analog dan beralih ke digital. Teknologi digital ini dipilih karena memiliki banyak kelebihan dibandingkan dengan teknologi analog. Adapun kelebihan teknologi digital adalah ketahanan terhadap efek interfrensi, derau dan fading; kemudahan untuk melakukan proses perbaikan terhadap kerusakan sinyal akibat proses transmisi dan memiliki kemampuan multipleks yang dapat menggabungkan beberapa program ke dalam satu kanal televisi $8 \mathrm{Mhz}$ dengan kualitas gambar yang jauh lebih baik. Selain itu penyiaran televisi digital memberikan aplikasi-aplikasi yang bisa interaktif seperti pengiklanan interaktif dan belanja jarak jauh.

Penyiaran televisi digital juga memiliki segmen pasar yang jauh lebih besar dibandingkan televisi analog. Saat ini, segmen pelanggan dari penyiaran televisi analog adalah penerima tetap (pelanggan perumahan) dan juga sedikit pelanggan bergerak (mobile). Dengan penyiaran digital, segmen pelanggan akan semakin besar karena adanya penambahan yang signifikan pada pelanggan yang bergerak karena kualitas gambar yang diterima pada perangkat mobile sudah berkembang menjadi jauh lebih baik. Bagi penyelenggara penyiaran televisi, teknologi ini mampu memberikan kualitas penerimaan sinyal yang baik dengan menggunakan stasiun pemancar yang dayanya lebih rendah dibandingkan stasiun pemancar analog. Single Frekuensi Network (SFN) adalah kelebihan lain dari teknologi ini, dengan SFN sebuah operator dapat memperluas area cakupannya dengan memasang sejumlah stasiun pemancar yang tersebar pada wilayah layanan yang luas namun beroperasi pada kanal frekuensi yang sama.

Bagi pemerintah sebagai regulator, kemampuan teknologi penyiaran digital yang dapat meyiarkan 4-8 program siaran digital dalam satu kanal televisi analog adalah sebuah usaha untuk meningkatkan efisiensi penggunaan spektrum frekuensi. Dengan spektrum frekuensi penyiaran yang ada saat ini dan dengan penggunaan spektrum frekuensi yang efisien, maka spektrum frekuensi yang ada dapat menampung lebih banyak penyelenggara penyiaran televisi baru dan juga layanan (service) lainnya. Hal tersebut tentunya juga dapat meningkatkan pendapatan negara dari Biaya Hak Penggunaan (BHP) Frekuensi.

Selain memberikan keuntungan, tentunya ada beberapa hal yang perlu dicermati, penyelenggaraan penyiaran televisi digital memberikan dampak finansial bagi penyelenggara yang ada berupa pengeluaran untuk menyediakan perangkat digital. Untuk mengatasi kendala-kendala tersebut dan untuk mendapatkan sebuah model penyelenggaraan yang tepat maka dibentuk sebuah model bisnis yang sesuai dengan kebutuhan masing-masing wilayah (negara). Munculnya beberapa model bisnis ini mendorong kita untuk melakukan peninjauan terhadap model bisnis yang ada untuk kemudian dapat menjadi rujukan dalam menentukan model bisnis yang tepat.

\section{METODE}

Metode yang digunakan dalam tulisan ini adalah metode kualitatif di mana pada tulisan ini akan dilakukan investigasi terhadap urgensi migrasi dari sistem penyiaran televisi analog ke televisi digital. Dampak dari sistem penyiaran televisi digital baik bagi operator, masyarakat dan pemerintah juga akan menjadi pembahasan berikutnya dalam tulisan ini. Investigasi terhadap penerapan sistem penyiaran digital di beberapa negara beserta model bisnis yang diterapkan adalah tahap lanjut yang akan dikemukakan sebelum melakukan analisa terhadap model bisnis penyiaran televisi digital yang berlaku pada umumnya. Hasil dari analisa model bisnis ini diharapkan dapat menjadi bahan rujukan ataupun saran untuk menentukan model bisnis penyelenggaraan penyiaran televisi. 


\section{Urgensi Migrasi Dari Sistem Penyiaran Televisi Analog ke Televisi Digital}

Sistem penyiaran televisi digital dapat memberikan keuntungan lebih dibandingkan dengan sistem analog. Sehingga, menjadi suatu keharusan untuk beralih (migrasi) ke sistem penyiaran digital. Dalam hal baik masyarakat sebagai pemirsa, penyelenggara televisi ataupun pemerintah sebagai regulator harus beralih ke penyiaran digital.

Yang menjadi keharusan bagi penyelenggara televisi dalam penyelenggaraan penyiaran televisi digital adalah terbukanya kesempatan-kesempatan baru dimana penyelenggara televisi dapat menawarkan layanan multimedia dan e-commerce melalui transmisi penyiaran digital. Sehingga, Efisiensi penggunaan spektrum frekuensi melalui program konten yang menawarkan berbagai macam kapasitas bandwidth yang bervariatif jika dibandingkan dengan transmisi yang digunakan melalui sistem analog dimana hal ini menghemat biaya.

Layanan universal secara komperatif mudah didapat melalui konten lokal. Konten yang lebih luas dan beragam dengan berbagai bahasa serta pembagian geografis di Indonesia. Selain itu, tersedia layanan-layanan baru yang bersifat interaktif dan ubiquitous. Selain itu, layanan penyiaran digital akan memudahkan penerapan konvergensi penyiaran dengan teknologi telekomunikasi serta teknologi informasi lain yang sangat diharapkan dan tidak dapat dielakkan. Dengan begitu, penerapan teknologi sistem digital ini mampu memberikan kualitas penerimaan sinyal yang tinggi dengan stasiun pemancar berdaya rendah dibanding dengan stasiun pemancar analog.

Keuntungan bagi pemirsa (masyarakat) dalam penyelenggaraan penyiaran televisi digital adalah program layanan yang ditawarkan lebih banyak dan tersedianya akses kepada layanan yang bernilai tambah yang juga dapat bertindak sebagai konten data tambahan. Selain itu, kualitas gambar yang lebih baik dan tersedia banyak layanan baru seperti messaging, teleconference, layanan profil, web surfing, e-commerce, dsb yang memberikan kesempatan lebih luas untuk memilih video dan pemrograman data. Selain itu, pemasangan dan operasionalisasi yang sederhana, tidak perlu adanya tambahan pemasangan parabola.

Keuntungan bagi pemerintah (regulator) dalam penyelenggaran penyiaran televisi digital adalah penyiaran televisi digital memberikan keuntungan secara sosial yang besar bagi pemerintah terutama teknologinya dapat digunakan untuk pendidikan jarak jauh. Selain itu, televisi digital meningkatkan efisiensi penggunaan spektrum, dimana satu kanal televisi analog dapat menyalurkan 48 program siaran digital. Sehingga, spektum digital dapat menampung lebih banyak penyelenggara televisi baru dan dapat memanfaatkan sebagian spektrum penyiaran yang ada untuk layanan lainnya yang dapat meningkatkan penerimaan negara dalam bentuk BHP frekuensi. Penyiaran digital dapat secara efektif mengirimkan layanan informasi beragam dalam hal layanan hiburan, seperti e-mail, internet dan sebagainya. Layanan tersebut akan menjadi bagian dari layanan universal pada masa yang akan datang.

\section{Dampak Sistem Penyiaran Digital}

Ada beberapa dampak yang ditimbulkan akibat penyelenggaraan sistem penyiaran televisi digital, baik bagi operator, masyarakat maupun pemerintah. Dampak sistem penyiaran digital bagi penyelenggara (operator) adalah digitalisasi memerlukan penggantian perangkat analog. Modal investasi yang mahal untuk penyediaan perangkat digital akan menjadi beban keuangan bagi lembaga penyiaran yang ada. Selain itu, dalam masa transisi siaran simulcast sistem analog dan digital, penyelenggara televisi harus mengeluarkan biaya operasional ganda karena harus membiayai pemancar analog dan digital sekaligus.

Dampak sistem penyiaran digital bagi pemirsa (masyarakat) adalah masyarakat harus mengadakan sendiri perangkat penerima digital untuk menggantikan perangkat analog atau paling 
tidak menggunakan set-top box yang dapat mengkonversi siaran televisi digital ke analog. Perangkat penerima dan peralatan yang mahal akan menjadi halangan tersendiri. Hal ini akan menjadi pengaruh negatif bagi suksesnya penyelenggaraan penyiaran televisi digital khususnya untuk masyarak kalangan ekonomi bawah.

Dampak sistem penyiaran digital bagi pemerintah (regulator) adalah diperlukan sosialisasi yang terus menerus kepada masyarakat yang kemungkinan akan memerlukan biaya besar karena kualitas kesadaran yang lambat dari masyarakat untuk beralih ke televisi digital. Berdasarkan perbandingan keharusan dan dampak penerapan sistem penyiaran digital, dapat dipahami bahwa penyelenggaraan sistem penyiaran digital adalah suatu keharusan karena memberikan keuntungan yang lebih besar dibandingkan kerugian yang dapat terjadi baik bagi operator, masyarakat maupun regulator. Disamping itu juga, dengan penyelenggaraan penyiaran televisi digital dapat menumbuhkembangkan industri dalam negeri baik industri konten maupun industri manufaktur elektronika dalam negeri. Peralihan ke sistem penyiaran televisi digital sudah tidak dapat dielakkan. Format analog sudah akan ditinggalkan, produksi akan berhenti dan akan menjadi mahal baik dari segi perangkat produksi, perangkat transmisi/pemancar maupun perangkat penerima televisi.

\section{Penerapan Sistem Penyiaran Digital di Beberapa Negara}

Sebagian besar negara-negara di dunia saat ini telah mulai melaksanakan migrasi dari sistem penyaiaran analog ke sistem penyiaran digital. Perkembangan sistem penyiaran televisi digital di Amerika, Jepang dan Eropa sudah dimulai beberapa tahun yang lalu. Bahkan di Amerika sudah menghentikan siaran analognya secara total (cut-off) di tahun 2009, begitu pula di Jepang di tahun 2011, dan negara-negara Eropa dan kawasan Asia juga akan mengikuti migrasi total dari sistem analog ke sistem digital. Selain itu, ada beberapa kesamaan dan alasan yang mendasari penerapan sistem penyiaran digital, antara lain: efisiensi daya pemancar dan efisiensi dalam penggunaan pita frekuensi (bandwidth), peningkatan kualitas gambar dan suara terlebih lagi bagi televisi bergerak (mobile) dan terbukanya peluang konvergensi dengan aplikasi lain (telepon seluler dan komputer), layanan multimedia, TV interaktif dan TV on demand.

\section{Penerapan Penyiaran Televisi Digital di Inggris}

Inggris memperkenalkan siaran televisi digital terestrial dengan standar DVB-T sejak tahun 1996 ketika pemerintah secara resmi mengumumkan pemberian lisensi untuk multipleks. Pada November 1998 sebuah stasiun TV mengudara dengan sistem tersebut yang diyakini merupakan siaran digital komersial pertama di dunia. Di akhir September 2006 populasi pemirsa DVB-T telah mencapai 73\% dan tahun 2007 sudah berada dalam tahap persiapan switch off TV analog secara bertahap dari satu wilayah ke wilayah lainnya.

Namun pemerintah Inggris mensyaratkan paling tidak dua kriteria untuk dapat dilakukan penghentian siaran TV analog. Kriteria pertama adalah availability (ketersediaan layanan) yaitu setiap orang yang sudah memperoleh layanan publik berupa siaran televisi analog harus dapat menerima siaran dalam format digital. Kriteria kedua adalah affordability (kemampuan daya beli) yaitu migrasi ke digital harus memberikan pilihan yang berguna kepada masyarakat luas. Penghentian siaran TV analog dilakukan secara bertahap yang dimulai dari kota - kota besar dan secara total di seluruh wilayah Inggris direncanakan dilakukan pada 1 Januari 2013

Model bisnis penyelenggaraan penyiaran TV digital di Inggris dibedakan menjadi tiga penyelenggaraan, yang terdiri dari : (1) Penyelenggara konten (content provider). (2) Penyelenggara multipleks (mux operator). (3) Penyelenggara jaringan (network operator). Pemerintah Inggris telah memberikan ijin kepada enam operator multipleks dengan setiap multipleks dapat menyalurkan 4-8 program siaran dari penyelenggara konten yang terdiri dari penyelenggara TV berbayar dan TV tidak berbayar (free to air). 
Pemberian ijin kepada enam operator multipleks membuat model penyelenggaraan penyiaran TV digital di Inggris berbeda dengan era penyiaran analog yang sebelumnya tidak mengenal ijin multipleks.

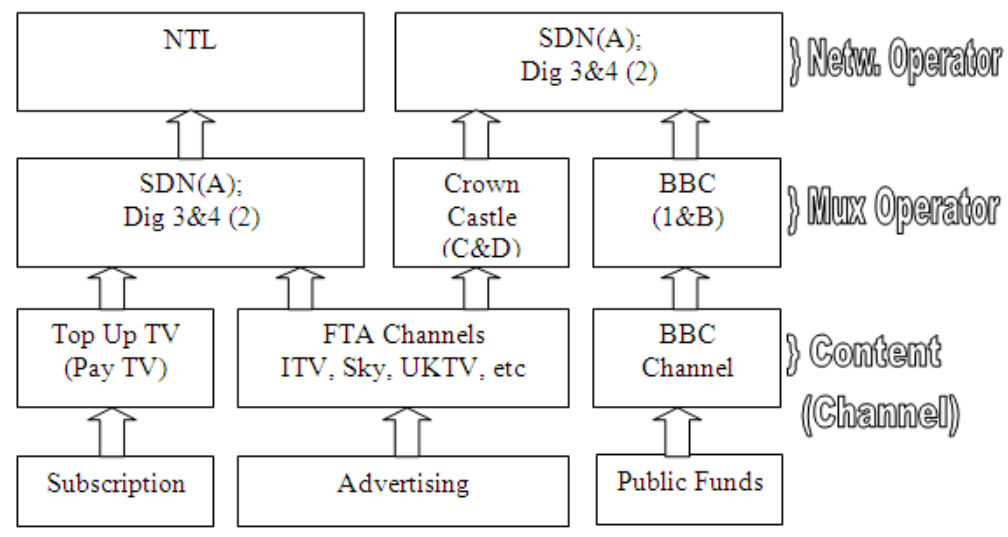

Gambar 1 Model Penyelenggaraan

TV Digital Terestrial Di Inggris

\section{Penerapan Penyiaran Televisi Digital di Perancis}

Di Perancis, DVB-T telah ditetapkan sejak tahun 2000 dan diperbaharui tahun 2004. Lembaga otoritas penyiaran Perancis, CSA (Conseil Superieur de I'Audiovisuel) telah menetapkan dan membagi siaran ke dalam enam multiplex untuk menyiarkan siaran TV digital di seluruh Perancis. Pada Bulan Februari 2007 Majelis Nasional Perancis menyetujui rancangan Undang-Undang baru bernama Television du Futur yang mengatakan bahwa penghentian siaran TV analog akan dilakukan per daerah mulai 31 Maret 2008 dan selesai 30 November 2011. Mulai Desember 2007 semua pesawat TV yang dijual harus dilengkapi dengan tunner digital dan televisi berformat HD akan dilengkapi dekoder HD MPEG4 AVC mulai 1 Desember 2008.

Setelah cut off TV analog, layanan TV digital akan dapat dinikmati oleh 95\% penduduk dan 5\% sisanya akan dapat mengakses siaran yang sama melalui transmisi satelit yang disediakan oleh pemerintah. Layanan satelit ini akan tersedia mulai Desember 2007. Saat ini di Perancis terdapat lima operator multiplex, yang dalam waktu dekat direncanakan menjadi enam. Masing-masing multiplex dapat menyiarkan antara 5-6 kanal yang ijinnya diberikan per kanal. Terdapat tiga operator jaringan yaitu TDF, Antalis dan Towercast yang dipilih oleh operator multiplex. Dalam model bisnis siaran televisi digital di Perancis, kanal siaran FTA dan TV berbayar disalurkan melalui beberapa multiplex. Kanal - kanal yang sama pada multiplex bekerjasama membentuk operator multiplex.

Operator multiplex dapat memilih salah satu dari tiga operator jaringan yang ada. ART sebagai lembaga yang melaksanakan perencanaan jaringan TV telah mengidentifikasi side mana yang akan dipergunakan dalam transmisi siaran. TDF sebagai penyedia jaringan televisi nasional dalam kenyataannya dapat mengontrol pengoperasian site transmisi dalam jumlah besar karena sebagian site tersebut berada di bawah pengawasannya. 


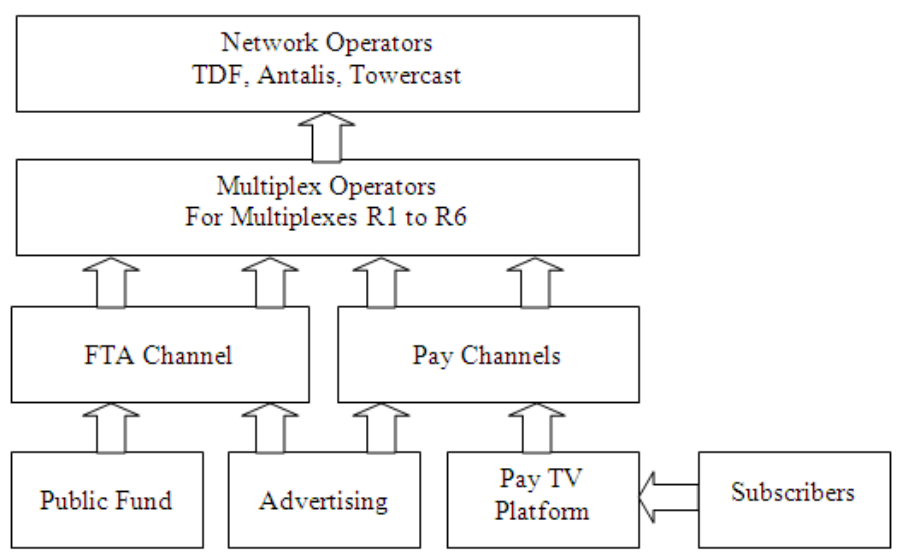

Gambar 2 Model Penyelenggaraan

TV Digital di Perancis

\section{Penerepan Penyiaran Televisi Digital di Australia}

Di Australia telah diluncurkan Digital Action Plan pada 23 November 2006, dengan tujuan untuk memberikan panduan untuk Australia untuk melakukan transisi ke televisi digital. Rencana ini berisi garis-garis besar dalam melakukan migrasi ke digital, termasuk pembentukan badan khusus migrasi yang bernama Digital Australia. Lembaga ini bertugas melakukan koordinasi dengan pemerintah, industri, pabrikan, regulator dan konsumen dalam persiapan migrasi. Negara ini telah secara resmi menentukan standar DVB-T sejak 2001 dan cut off analog diharapkan dapat terjadi antara 2010 dan 2012. Pemerintah telah melakkukan percobaan penyiaran digital sejak tahun 1998 dan akhir Juni 2006 diperkirakan sudah lebih dari 1,74 juta digital TV receiver terjual atau sekitar 23\% dari 7,6 juta total populasi penduduk yang memiliki pesawat televisi. Negara ini juga telah melakukan uji coba DVB-H yang dilakukan oleh Bridge Network dan uji coba MHP TV interaktif oleh stasiun TV SBS.

Dalam implementasi penyiaran televisi digital di Australia, masing-masing penyelenggara penyiaran TV analog yang ada mendapatkan tambahan alokasi kanal frekuensi untuk penyiaran digital. Ijin frekuensi radio diberikan kepada penyelenggara penyiaran namun untuk efisiensi dalam prakteknya pembangunan infrastruktur penyiaran dilakukan oleh penyelenggara jaringan. Dengan demikian, dalam penyelenggaraan penyiaran digital di Australia dapat dipisahkan menjadi dua bagian, yaitu penyelenggara program siaran (Content Provider) dan penyelenggara jaringan (Network Provider). Infrastruktur penyiaran dibangun sepenuhnya oleh penyelenggara jaringan sesuai dengan permintaan kapasitas saluran oleh penyelenggara program siaran.

\section{Penerepan Penyiaran Televisi Digital di Jepang}

Jepang yang dikenal sebagai negara yang mengembangkan teknologi ISDB, memiliki potensi pasar siaran TV yang tinggi. Sejak diperkenalkan setengah abad yang lalu, televisi siaran terestrial telah menjadi pilihan utama bagi masyarakat Jepang dalam memperoleh informasi. Perkembangan televisi digital di Jepang secara resmi ditandai dengan dikeluarkannya keputusan mengenai proses perijinan stasiun penyiaran digital terestrial pada 27 Spetember 2002 oleh MPHPT (the Ministry of Public Management, Home Afffairs, Posts and Telecommunicaton). Keputusan itu sejalan dengan rencana dasar penyiaran untuk melakukan migrasi penyiaran analog ke digital secara dini dan lancar. Pelaksanaan siaran dilakukan pada 2003 di kota-kota metropolitan seperti Kanto, Chukyo dan Kinki. Daerah lainnya dilakukan pada tahun 2006. 
Sejak dikeluarkannya ijin penyiaran digital, perkembangan siaran televisi digital di Jepang berlangsung sangat cepat, hal ini ditandai dengan dilakukannya uji coba implementasi akses internet pada televisi digital dan juga siaran HDTV melalui penerimaan begerak. Model bisnis penyelenggaraan penyiaran televisi digital di Jepang sama dengan model bisnis penyelenggaraan penyiaran televisi analog. Penyelenggara televisi bertindak sebagai penyelenggara konten dan sekaligus penyelenggara jaringan. Dalam hal ini setiap penyelenggara televisi analog yang ada, masing-masing diberikan ijin frekuensi dan membangun sendiri infrastruktur penyiarannya. Dalam prakteknya untuk efisiensi dan keindahan kota, penyelenggara televisi menggunakan menara pemancar secara bersama (sharing), seperti penggunaan Tokyo Tower untuk semua penyelenggara televisi yang ada di Tokyo.

\section{Penerapan Penyiaran Televisi Digital di Malaysia}

Pemerintah Malaysia menetapkan DVB-T sebagai standar bagi penyiaran televisi digital. Penyiaran televisi digital di Malaysia sudah dirintis sejak 1998. Secara resmi, pada tahun 2006, pemerintah melakukan uji coba siaran digital yang dilakukan di daerah Klang Valley dengan melibatkan sekitar 1000 pemirsa di rumah. Uji coba menggunakan satu multiplex pada channel 44 UHF menggunakan mode 8k, yang mampu menyediakan lima program TV dan tujuh program siaran radio, yang kemudian akan dikembangkan secara bertahap dengan dana awal 75 juta ringgit. Selama periode uji coba ini akan dilakukan beberapa tes termasuk uji coba layanan interaktif.

Dalam masa transisi dan untuk mempercepat proses migrasi ke digital, MCMC mengijinkan dibentuknya common integrated infrastructur provider yang merupakan gabungan Mux Provider dan Network Provider. Dengan demikian selama masa transisi, di Malaysia terdapat dua penyelenggara, yaitu penyelenggara infrastruktur (gabungan dari Mux Provider dan Network Provider) dan penyelenggara konten (Content Provider). Dalam implementasinya, MCMC mengharuskan penyelenggara siaran televisi digital untuk menggunakan lokasi dan tower bersama bagi TV publik dan TV swasta untuk efisiensi biaya dan memudahkan masyarakat mengarahkan antenanya.

\section{HASIL DAN PEMBAHASAN}

Berdasarkan studi perbandingan (Benchmarking) di beberapa negara maju dan berkembang, terdapat tiga jenis model bisnis penyelenggaraan penyiaran televisi digital yaitu: (1) Penyelenggara penyiaran yang menyatu antara penyelenggara konten dan penyelenggara jaringan. (2) Pemisahan penyelenggara penyiaran menjadi dua bagian yaitu penyelenggara konten dan penyelenggara jaringan. (3) Pemisahan penyelenggara penyiaran menjadi tiga bagian yaitu penyelenggara konten, penyelenggara multipleks dan penyelenggara jaringan.

\section{Penyelenggara Penyiaran Yang Menyatu Antara Penyelenggara Konten dan Penyelenggara Jaringan.}

Dalam hal ini tidak terjadi perubahan pada struktur penyelenggaraan yang ada, artinya penyelenggara penyiaran televisi analog yang ada masing-masing diberikan tambahan satu kanal frekuensi untuk migrasi ke penyiaran televisi digital. Penyelenggara televisi yang ada diberikan kebebasan sepenuhnya untuk melakukan proses migrasi ke sistem penyiaran digital dengan memanfaatkan tambahan satu kanal frekuensi digital. Lembaga penyiaran menyelenggarakan program siaran (konten) dan sekaligus mengoperasikan jaringan penyiaran dengan membangun sendiri infrastruktur penyiaran termasuk perangkat pemancar dan jaringan transmisinya. 
Model penyelenggaraan ini dapat dilakukan kalau jumlah penyelenggara yang ada dalam satu wilayah layanan tidak begitu banyak sehingga masih tersedia alokasi frekuensi tambahan yang cukup bagi masing-masing penyelenggara dalam menyelenggarakan penyiaran televisi digital. Keuntungan model penyelenggaraan ini penyedia konten akan memiliki sistem studio dan transmisi yang tidak berbeda dengan sistem analog dan mengawasi serta mengontrol keseluruhan rantai penyiaran mulai dari studio produksi sampai kepada pemancar dan transmisinya. Selain itu, penyedia konten akan menguasai keahlian untuk keseluruhan rantai penyiaran.

Sementara, Kerugian model penyelenggaraan ini adalah penggunaan frekuensi menjadi tidak efisien, tidak menunjukkan frekuensi sebagai sumber daya yang langka, masing-masing lembaga penyiaran yang ada diharuskan memperoleh frekuensi. Lembaga penyiaran akan memiliki multipleks yang mungkin tidak sepenuhnya digunakan. Hal ini berkaitan dengan kenyataan bahwa stasiun penyiaran mungkin tidak memiliki cukup program untuk memanfaatkan semua kapasitas kanal yang tersedia dalam multipleks.

Merupakan sesuatu yang mahal bagi suatu operator untuk memiliki sebuah multipleks yang tidak dimanfaatkan secara penuh. Lembaga penyiaran yang ada akan terbebani secara keuangan karena harus membiayai sendiri pengadaan perangkat pemancar digital dalam masa transisi. Dari sisi perkiraan biaya investasi, model bisnis seperti ini membutuhkan dana investasi sebesar US\$465,300 atau sebesar 4,3 milyar rupiah untuk setiap pengadaan perangkat digital pada stasiun pemancar dengan kapasitas satu program siaran dalam satu kanal frekuensi.

\section{Pemisahan Penyelenggara Penyiaran Menjadi Penyelenggara Konten dan Penyelenggara Jaringan.}

Penyelenggara konten siaran yaitu pihak yang menyediakan program untuk disiarkan. Penyelenggara konten adalah penyelenggara penyiaran televisi analog yang ada saat ini. Penyelenggara jaringan yaitu pihak yang memiliki kewajiban untuk membangun infrastruktur pemancar televisi digital. Infrastruktur yang dimaksud meliputi antara lain pemancar termasuk multiplexer, antena pemancar dan menara.

Keuntungan dari pemisahan ini adalah penyelenggara penyiaran televisi yang ada sebagai penyelenggara konten akan berkonsentrasi dalam membuat lebih banyak konten dan menikmati nilai ekonomisnya tanpa harus memikirkan pembangunan sarana dan prasarana perangkat pemancar beserta jaringan transmisinya. Menjamin efisiensi penggunaan spektrum frekuensi karena satu kanal frekuensi dapat digunakan secara bersama oleh $4-8$ penyelenggara konten. Selain itu, pemisahan ini mendorong penggunaan bersama menara dan lokasi transmisi, mengurangi biaya manajemen yang dipergunakan untuk mengontrol rantai transmisi dan perluasan jaringan, mengurangi biaya pekerja (SDM) dan administrasi yang mengurusi jaringan transmisi dan ramah lingkungan, sebagai contoh: mengurangi menjamurnya penggunaan menara. Sementara, kerugian dari pemisahan ini adalah penyelenggara siaran televisi yang ada, tidak dipekenankan memiliki ijin frekuensi sehingga tidak dapat lagi mengontrol jaringan transmisi siaran.

Dari sisi perkiraan biaya investasi, model bisnis seperti ini membutuhkan dana investasi sebesar US\$845,200 atau sebesar Rp7,8 milyar untuk setiap stasiun pemancar dengan dua kanal frekuensi atau dua multiplexer dengan kapasitas 12 slot saluran program siaran televisi digital. Dengan demikian biaya investasi untuk setiap slot program siaran adalah sebesar US\$70,433 atau Rp655 juta.

\section{Pemisahan Penyelenggara Penyiaran Menjadi Penyelenggara Konten, Penyelenggara Multipleks dan Penyelenggara Jaringan.}

Model bisnis ini hampir sama dengan model sebelumnya hanya ada tambahan penyelenggara baru yaitu penyelenggara multipleks yang sebelumnya merupakan bagian dari penyelenggara jaringan. 
Penyelenggara multipleks bertindak sebagai penyatu program siaran (content agregator) yang mengatur distribusi kapasitas laju data dalam satu kanal frekuensi untuk digunakan oleh bermacammacam jenis program siaran agar efisien dan optimal. Penyelenggara multipleks harus bersifat netral dalam mengatur distribusi kapasitas laju data dari program - program siaran. Dalam hal ini, ijin frekuensi diberikan kepada penyelenggara multipleks sementara ijin penyelenggara siaran diberikan kepada penyelenggara konten siaran. Sedangkan penyelenggara jaringan lebih fokus kepada sistem transmisi dan penyediaan infrastrukur seperti menara.

Keuntungan dari pemisahan menjadi tiga bagian ini adalah pembangunan infrastruktur penyiaran dapat berjalan dengan cepat sebab penyelenggara jaringan akan berkonsentrasi hanya pada pemasangan transmisi sementara pengaturan distribusi program dan optimalisasi kapasitas multipleks diserahkan sepenuhnya kepada penyelenggara multipleks. Selain itu, investasi dalam penyelenggaraan penyiaran televisi digital akan berkurang karena modal investasi didistribusikan kepada ketiga pemain utama yaitu penyelenggara program siaran, penyelengara multipleks dan penyelenggara jaringan.

Sementara, kerugian dari pemisahan menjadi tiga bagian ini adalah proses penghantaran layanan konten siaran kepada masyarakat menjadi lebih rumit karena melibatkan tiga pemain utama penyelenggara program siaran, penyelengara multipleks dan penyelenggara jaringan. Karena ketiga pihak saling bergantung dalam pemberian layanan konten pada masyarakat, jika satu pihak melanggar persyaratan yang ditetapkan maka akan menggangu dan menghalangi pengantaran kepada masyarakat.

\section{SIMPULAN}

Berdasarkan analisa perbandingan keuntungan dan kekurangan dari masing-masing tiga model di atas, dapat disimpulkan sebagai berikut: Pertama, model bisnis pertama dimana penyelenggara konten dan penyelenggara jaringannya menyatu, memiliki banyak kekurangan dan membutuhkan nilai investasi yang besar dalam proses migrasi ke televisi digital. Terlihat juga penggunaan frekuensi yang tidak efisien dimana pada penggunaannya tidak tergambar bahwa frekuensi adalah sumber daya yang langka. Kedua, model bisnis kedua, penyelenggara konten dan penyelenggara jaringan terpisah, memperlihatkan banyak keuntungan khususnya dari sisi biaya investasi. Besaran biaya investasi hanya sebesar 15,23\% dari model bisnis yang pertama. Dengan model bisnis ini, kita juga dapat melihat adanya penggunaan frekuensi yang efisien, dimana satu kanal frekuensi dapat dimanfaatkan 4-8 penyelenggara konten. Hal ini menunjukkan kelangkaan frekuensi sebagai sumber daya. Dari sisi penyelenggara konten, biaya yang ditanggung menjadi lebih kecil karena tanggung jawab pembangunan infrastruktur penyiaran sepenuhnya berada pada penyelenggara Jaringan. Penggunaan perangkat transmisi yang dapat digunakan bersama juga memberikan nilai tambah dalam hal tata ruang dan penggunaan sumber daya. Ketiga, model bisnis ketiga, penyelenggara konten, penyelenggara multipleks dan penyelenggara jaringan terpisah, model bisnis seperti ini sangat rumit dalam menghantarkan layanan konten siaran kepada masyarakat. Hal ini dikhawatirkan dapat memperlambat proses migrasi karena diperlukan koordinasi yang sangat baik antara ketiga entitas yang ada terlebih lagi ketika melakukan konvergensi teknologi yang kompleksitasnya tinggi. 


\section{DAFTAR PUSTAKA}

Australian Broadcasting Authority. (2005). Digital Terrestrial Television Broadcasting Planning Handbook including technical and general assumption. Canberra: Australian Broadcasting Authority (ABA).

Ditjen Postel. (2008). Model Usaha dalam Penyelenggaraan Penyiaran Televisi dan Radio Digital. Presentasi oleh Ditjen Postel.

Rustandi, L. (2006). Migrasi dari Sistem Penyiaran Analog ke Digital di Indonesia. Presentasi oleh Lilik Rustandi, Denpasar.

RTM Malaysia. (2007). RTM’s DTTB Trial and Future Digital Plan. Presentasi oleh RTM Malaysia, Kuala Lumpur.

Nobuyuki, K. (2008). References Terrestrial TV Broadcasting Migration from Analogue to Digital in Japan. Presentasi oleh Kondo Nobuyuki, Jica Expert. 